\title{
TINGKAT KESUKAAN TILIAYA (MAKANAN TRADISIONAL GORONTALO) YANG MENGGUNAKAN JENIS TELUR BERBEDA
}

\author{
Muchlis Hippy1), Siswatiana R. Taha2), Muhammad Sayuti22). \\ 1. Animal husbandry department alumni, Faculty of agriculture, Gorontalo state university \\ 2. Animal husbandry departmen, Faculty of agriculture, Gorontalo state university \\ muhlishippy@gmail.com, tahasiswatiana@gmail.com, muhammadsayuti@ung.ac.id.
}

\begin{abstract}
The Research aimed to knowing the effect of using different type eggs to favourite level of Tiliaya (Gorontalo traditional food), includes: texture, color, smell, taste and preference in general. The panelists used were 25 people of untrained category with range score 1 to 5 . This research used a completely randomized design (CRD) with four treatments and four replications. The treatments was P1 (chicken eggs), P2 (free-range eggs), P3 (duck eggs) and P4 (quail eggs). Data analysis used analysis of variance and continued with Duncan's multiple range test (DMRT). The result of research showed that had a significant effect $(\mathrm{P}>0,01)$ to treatments. About texture of Tiliaya, panelists gave highest score on treatment P3 (duck eggs) with average value of 4,14. Based on color, treatment P2 (free-range chicken eggs) gets highest average score of 4,22, while treatment P1 (chicken eggs) gets the highest average value in terms of smell, taste and preference. In conclusion, using different type eggs namely chicken eggs, free-range chicken eggs, duck eggs, and quail eggs had affect organoleptic characteristics both in terms of texture, color, smell, taste and pereference in general of Tiliaya (Gorontalo traditional food).
\end{abstract}

Keywords : Organoleptic Test, Tiliaya, Type of Eggs.

\section{PENDAHULUAN}

Telur merupakan salah satu produk ternak yang berasal dari unggas yang sempurna, karena mengandung zatzat gizi yang lengkap bagi pertumbuhan mahluk hidup baru. Protein telur memiliki susunan asam amino esensial yang lengkap sehingga dijadikan standar untuk menentukan mutu protein dari bahan lain. Selain itu, telur juga merupakan salah satu produk utama yang dihasilkan unggas dengan nilai gizi tinggi, karena mengandung zat-zat makanan yang dibutuhkan oleh tubuh seperti protein, vitamin, dan mineral serta memiliki daya cerna yang tinggi, cocok untuk semua lapisan masyarakat baik anak-anak maupun orang tua. Kegunaan yang paling umum adalah untuk lauk pauk, selain itu telur juga bisa dibuat sebagai makanan olahan tradisional seperti Tiliaya.

Tiliaya merupakan makanan khas tradisional masyarakat Gorontalo yang bahan dasarnya terbuat dari telur, santan kelapa serta gula merah. Selain itu, Menurut Rigap, (2013) Tiliaya merupakan pilihan makanan khas malam pertama sahur orang Gorontalo tempo dulu. Makanan berupa kukusan yang terbuat dari gula merah, telur dan santan ini hanya di makan pada saat sahur. Menurut sejarahnya, makanan ini pertama kalinya dibuat oleh seorang putri raja gorontalo yang juga bernama Tiliaya dan dijadikan sebagai makanan khas kaum bangsawan terutama disajikan untuk menyambut tamu kehormatan kerajaan. Lama kelamaan, seiring berubahnya sistem 
pemerintahan di daerah Gorontalo, biasanya makanan khas ini sering disajikan dalam acara-acara seperti pembeatan, khitanan, perkawinan peringatan hari-hari besar hingga acara resmi pemerintahan Gorontalo dan juga disajikan dalam do'a arwah (tradisi Gorontalo mendoakan orang yang telah meninggal dunia. Kebanyakan orang membuat telur ayam dengan menggunakan telur ayam ras, namun dalam perkembangannya sebagian orang lebih memilih menggunakan telur ayam kampung, telur bebek bahkan telur puyuh.

\section{METODE PENELITIAN}

Penelitian telah dilaksanakan bulan Desember 2018 sampai dengan bulan Januari 2019 bertempat di Laboratorium Terpadu Fakultas Pertanian Universitas Negeri Gorontalo. Bahan yang digunakan antara lain telur ayam ras, telur ayam kampung, telur itik, telur puyuh, gula merah (serut), santan kelapa, dan air. Sedangkan alat yang digunakan dalam penelitian ini adalah panci kukus, wadah, pengocok telur, kompor gas, sendok, gelas ukur, timbangan elektrik 250 gr, timbangan model KCA 200 gr.

\section{Prosedur Pembuatan Tiliaya}

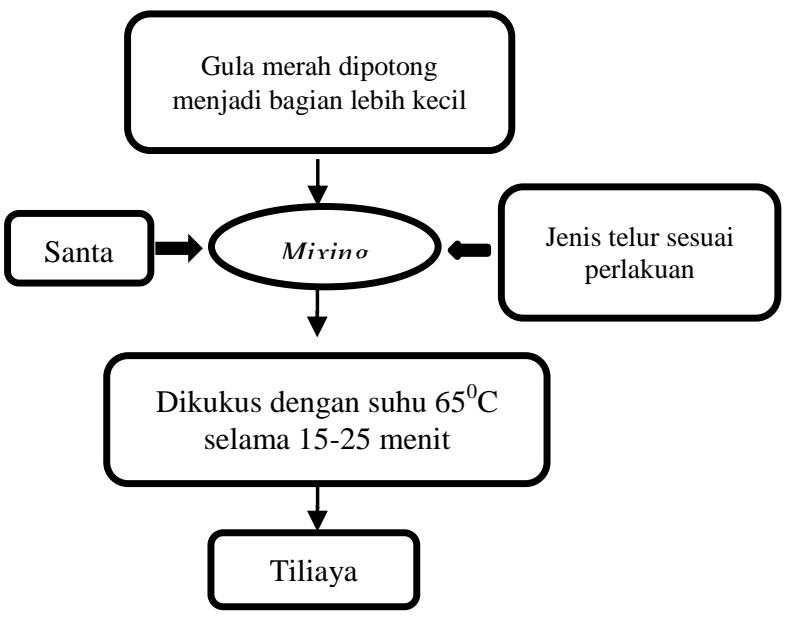

\section{Parameter}

Parameter yang di amati panelis adalah tingkat kesukaan Tiliaya meliputi tekstur, aroma, warna, rasa, dan kesukaan secara umum dengan menggunakan range skore 1 sampai 5. Data yang diperoleh dianalisis menggunakan analisis ragam (analysis of varians) dan uji Duncan atau Duncan's multiple range test (DMRT).

\section{HASIL DAN PEMBAHASAN}

Tekstur Tiliaya

Tekstur pada Tiliaya umumnya dipengaruhi oleh jenis komposisi bahan yang digunakan. dilihat dari tingkat kehalusan. Hasil rata-rata penilaian panelis terhadap tekstur Tiliaya dapat dilihat pada Gambar 1.

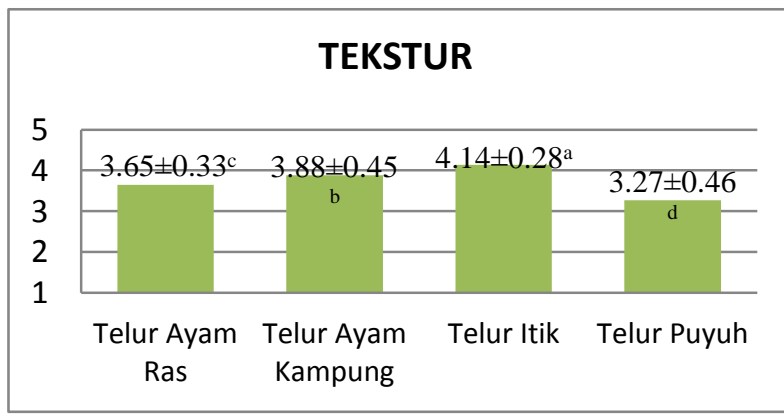

Gambar 1. Diagram Nilai Rata-rata tekstur Tiliaya. Superskrip yang berbeda pada setiap angka menunjukkan perbedaan sangat nyata $(\mathrm{P}<0,01)$ berdasarkan uji lanjut Duncan (DMRT)

Berdasarkan Gambar 2, penilaian panelis terhadap tekstur Tiliaya berkisar antara 3,27 - 4,14. Hasil analisis ragam menunjukan bahwa penggunaan jenis telur yang berbeda berpengaruh sangat nyata $(\mathrm{P}<0,01)$ terhadap tekstur Tiliaya. Hasil uji lanjut Duncan menujukkan bahwa hasil penilaian panelis terhadap tekstur Tiliaya juga berbeda antara masing-masing perlakuan yang diberikan.

Menurut Kartika, dkk. (1988) bahwa panelis cenderung lebih menyukai tekstur yang halus atau lembut, empuk dan tidak keras. Sebaliknya, panelis akan memberi skor yang lebih rendah terhadap produk makanan yang teksturnya kasar dan keras. Tekstur merupakan sensasi tekanan yang dapat diamati dengan mulut (pada waktu digigit, dikunyah, dan ditelan) ataupun perabaan dengan jari atau menggunakan alat bantu seperti sendok. 


\section{Aroma Tiliaya}

Aroma adalah rasa dan bau yang sangat subjektif serta sulit diukur, karena setiap orang memiliki sensifitas dan kesukaan yang berbeda.Timbulnya aroma pada produk pangan disebabkan oleh terbentuknya senyawa yang mudah menguap. Aroma yang dikeluarkan setiap produk pangan berbeda-beda (Busyro, 2013). Hasil nilai rata-rata pengujian organoleptik terhadap aroma Tiliaya dapat dilihat pada Gambar 2.

Hasil ANOVA pada Lampiran 3 menujukkan bahwa penggunaan jenis telur yang berbeda sebagai bahan baku utama produk Tiliaya berpengaruh sangat nyata $(\mathrm{P}<0,01)$ terhadap aroma Tiliaya. Sedangkan, pada uji lanjut Duncan terdapat perbedaan antara semua perlakuan terhadap aroma, kecuali antara Tiliaya yang menggunakan telur ayam kampung dan telur itik, serta Tiliaya yang menggunakan telur itik dan telur puyuh memiliki hasil tidak berbeda.

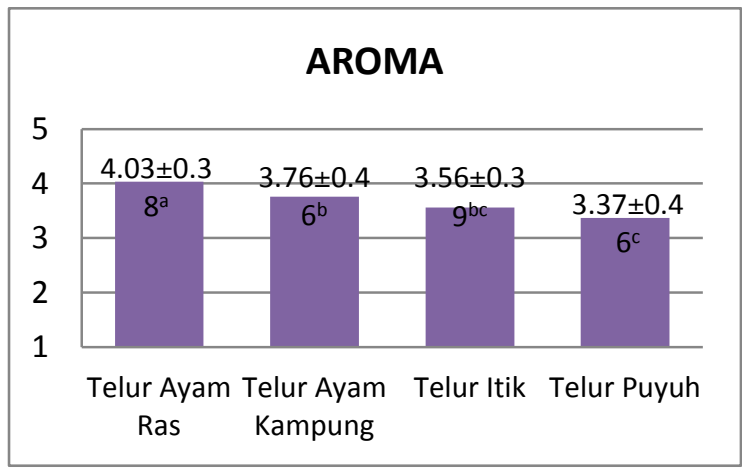

Gambar 2. Diagram Nilai Rata-rata Aroma Tiliaya.Superskrip yang berbeda pada setiap angka menunjukkan perbedaan sangat nyata $(\mathrm{P}<0,01)$ berdasarkan uji lanjut Duncan (DMRT)

Aroma pada Tiliaya terbentuk dari campuran bahan yang digunakan antara lain telur, santan dan gula merah. Dalam penelitian ini, panelis memberikan nilai rata-rata tertinggi yaitu 4,03 terhadap aroma pada perlakuan yang menggunakan telur ayam ras. Hal ini berarti, aroma khas Tiliaya terdapat produk dengan penggunaan jenis telur ayam ras.Hasil ini diduga disebabkan karena produk Tiliaya yang banyak dijumpai ditengah masyarakat umumnya menggunakan jenis telur ayam ras. Sehingga, penentuan aroma yang khas panelis lebih cenderung memilih perlakuan yang menggunakan jenis telur ayam ras sebagai bahan dasar pembuatan Tiliaya tersebut.Pencampuran antara beberapa bahan yang berbeda akan menimbulkan aroma yang khas pula (Saputra, dkk. 2015).

Warna Tiliaya

Menurut Padaga, dkk. (2005) Warna makanan memegang peranan utama dalam penampilan makanan.Sedangkan, menurut Pracoyo (2017) bahwa warna salah satu karakteristik penting yang menjadi referensi konsumen dalam memilih suatu produk makanan. Sehingga warna dapat dikatakan sebagai salah satu faktor utama yang diamati atau dilihat oleh konsumen untuk bisa tertarik pada produk makanan tersebut. Hasil penilaian rata-rata uji organoleptik terhadap warna Tiliaya dapat dilihat pada Gambar 3.

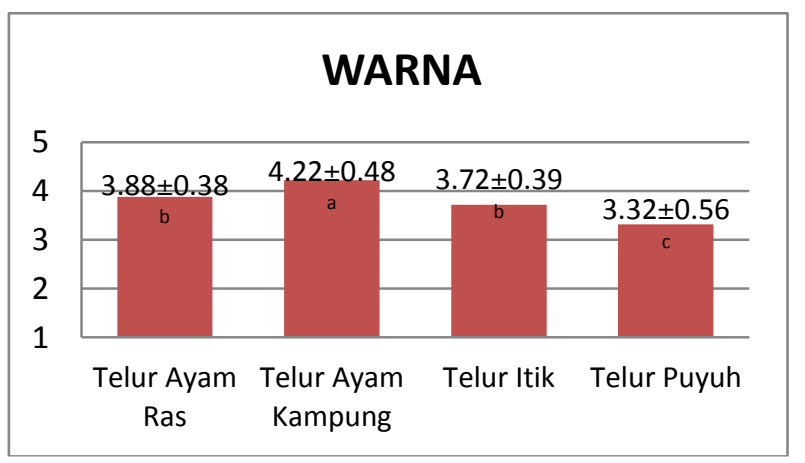

Gambar 3. Diagram Nilai Rata-rata Warna Tiliaya. Superskrip yang berbeda pada setiap angka menunjukkan perbedaan sangat nyata $(\mathrm{P}<0,01)$ berdasarkan uji lanjut Duncan (DMRT).

Penilaian panelis terhadap karakteristik warna Tiliaya yang menggunakan jenis telur berbeda memiliki kisaran skor antara 3,32-4,22. Hasil analisis ragam menujukkan bahwa penggunaan jenis telur yang berbeda memberikan pengaruh sangat nyata $(\mathrm{P}<0,01)$ terhadap warna Tiliaya. Berdasarkan uji lanjut Duncan bahwa perbedaan antara semua perlakuan terhadap warna Tiliaya, kecuali antara 
perlakuan Tiliaya yang menggunakan telur ayam ras dan telur itik.

Penilaian warna Tiliaya tertinggi terdapat pada perlakuan yang menggunakan telur ayam kampung dengan nilai rata-rata 4,22 dalam kategori cokelat hingga sangat cokelat, hal ini dikarenakan komponen penyusun asam amino yang terkandung dalam telur ayam kampung lebih lengkap dan lebih tinggi dibandingkan dengan susunan asam amino jenis telur unggas lainnya. Hal ini sesuai dengan pendapat Kunsah, (2017) yang mengemukakan bahwa kelebihan telur ayam kampung adalah komposisi asam amino lebih lengkap dan lebih tinggi dibandingkan dengan jenis telur unggas lainnya. Seperti yang telah dibahas sebelumnya bahwa reaksi pencokelatan akan semakin meningkat jika komponen penyusun asam amino semakin lengkap. Oleh karena itu, produk Tiliaya yang menggunaka jenis telur ayam kampung memiliki warna yang lebih cokelat jika dibandingkan dengan Tiliaya yang menggunakan jenis telur ayam ras, telur itik, maupun telur puyuh.

Rasa Tiliaya

Rasa merupakan salah satu parameter yang menjadi bagian penilaian dalam uji organoleptik ini dan memegang perananan yang cukup penting dalam menentukan tingkat kesukaan Tiliaya ini. Karena, walaupun secara eksterior memiliki tingkat penilaian yang bagus tetapi memiliki rasa yang kurang enak maka akan menurunkan tingkat kesukaan terhadap produk yang ditawarkan tersebut. Hasil penilaian rata-rata terhadap rasa Tiliaya dengan menggunakan perlakuan jenis telur yang berbeda disajikan pada Gambar 4 .

Diagram penilaian rata-rata terhadap rasa Tiliaya menujukkan bahwa penilaian organoleptik terhadap rasa Tiliaya berkisar antara 3,66 - 4,20. Hasil menujukkan bahwa penggunaan jenis telur berpengaruh sangat nyata $(\mathrm{P}<0,01)$ terhadap hasil penilaian uji organoleptik rasa produk Tiliaya

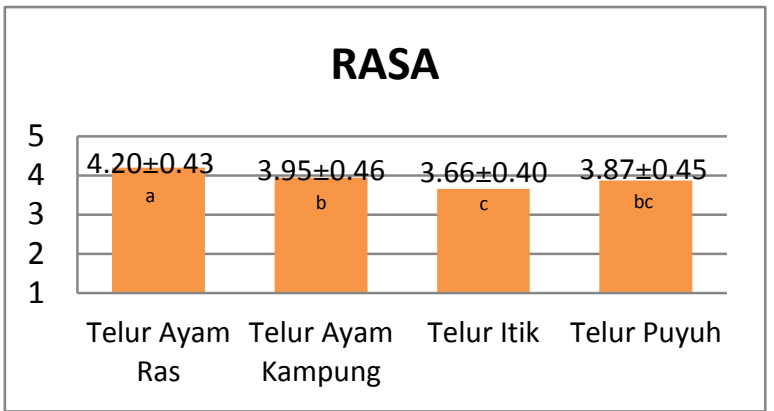

Gambar 4. Diagram Nilai Rata-rata Rasa Tiliaya. Superskrip yang berbeda pada setiap angka menunjukkan perbedaan sangat nyata $(\mathrm{P}<0,01)$ berdasarkan uji lanjut Duncan (DMRT).

Uji lanjut Duncan menujukkan adanya perbedaan antara Tiliaya yang menggunakan telur ayam ras, telur ayam kampung, telur itik dan telur puyuh. Namun, antara Tiliaya yang menggunakan telur ayam kampung dan telur puyuh serta telur puyuh dan telur itik tidak menjukkan perbedaan.

Dalam penelitian ini, panelis lebih menyukai rasa Tiliaya yang berbahan dasar telur ayam ras, dibuktikan dengan panelis memberikan nilai rata-rata paling tinggi $(4,29)$ pada Tiliaya yang menggunakan telur ayam ras dengan kategori enak sampai sangat enak. Hal ini diduga karena komposisi telur ayam ras yang cocok dipadukan dengan bahan lainnya seperti santan dan gula merah menimbulkan rasa yang sangat enak bagi panelis. Karena, perpaduan komposisi yang terkandung dalam bahan suatu produk yang sesuai akan lebih menimbulkan rasa yang enak dalam produk makanan tersebut (Heru, 2017).

Kesukaan Tiliaya

Hasil rata-rata pengujian organoleptik terhadap tingkat kesukaan Tiliaya dapat dilihat pada Gambar 5.

Berdasarkan diagram rata-rata diketahui bahwa tingkat kesukaan panelis terhadap produk Tiliaya berkisar antara 3,66-4,24. 


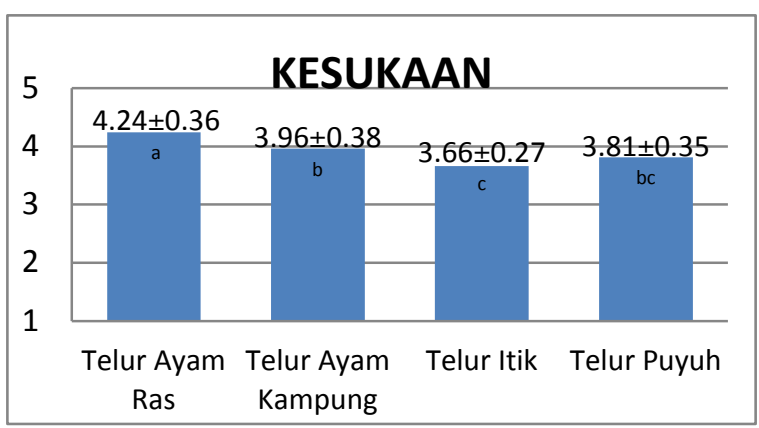

Gambar 5. Diagram Nilai Rata-rata Kesukaan Tiliaya. Superskrip yang berbeda pada setiap angka menunjukkan perbedaan sangat nyata $(\mathrm{P}<0,01)$ berdasarkan uji lanjut Duncan (DMRT).

Hasil analisis ragam menunjukkan hasil berbeda sangat nyata $(\mathrm{P}<0,01)$ terhadap tingkat kesukaan panelis terhadap Tiliaya. Berdasarkan uji lanjut Duncan, Tiliaya yang menggunakan telur ayam ras berbeda dengan yang menggunakan telur ayam kampung, telur itik dan telur puyuh., sedangkan antara Tiliaya yang menggunakan telur ayam kampung dan telur puyuh, serta antara telur itik dan telur puyuh menujukkan hasil tidak berbeda.

Penilaian tertinggi panelis terhadap tingkat kesukaan Tiliaya terdapat pada perlakuan yang menggunakan telur ayam ras yaitu 4,24. Hal ini dikarenakan pada paremeter pengujian terhadap rasa Tiliaya perlakuan yang menggunakan telur ayam ras juga mendapatkan hasil penilaian panelis yang tinggi dibandingkan dengan perlakuan lainnya. Lekahena, (2018) mengemukakan bahwa rasa dari suatu produk merupakan parameter utama yang sangat mempengaruhi tingkat penerimaan atau tingkat kesukaan konsumen terhadap produk tersebut. Walaupun parameter lainnya baik, tetapi konsumen (panelis) akan menolak produk yang tidak disukai rasanya. Pendapat lain juga mengatakan bahwa jika komponen aroma, warna dan tekstur baik tetapi konsumen tidak menyukai rasanya makan konsumen tidak akan menerima produk pangan tersebut (Rakhmah, 2012).

\section{KESIMPULAN}

Penggunaan jenis telur sebagai bahan dasar dalam pembuatan Tiliaya dapat memberikan pengaruh terhadap tingkat kesukaan produk Tiliaya tersebut baik dari segi tekstur, aroma, warna, dan rasa.

\section{Saran}

Penelitian lanjutan tentang uji analisis mutu kimia terhadap Tiliaya (Makanan Tradisional Gorontalo) tersebut.

\section{DAFTAR PUSTAKA}

Busyro, M. 2013. Laporan Praktikum Penilaian Sensori Pangan (Cicip, $\mathrm{BAu}$, Aroma dan Rasa Makanan. Online.https://muzhoffarbusyro.w ordpress.com. Diakses pada 12 Januari 2019.

Heru, S. 2017. Kualitas Organoleptik Olahan Telur Itik dengan Penambahan Bawang Putih (Allium sativum) dan Cabai (Capsicum annum 1) pada Lama Penyimpanan yang Berbeda.Skripsi. Fakultas Peternakan, Universitas Hasanuddin Makassar.

Kunsah, B. 2017. Analisa Kadar Protein Telur Ayam Kampung (Gallus domesticus) terhadap Lama Penyimpanan Pada Suhu12$15^{\circ} \mathrm{C}$.Journal of Muhammadiyah Medical Laboratory Technologist, Vol. 2 (1).Hal.54-63.

Lekahena, V.N. 2017. Tingkat Kesukaan Konsumen Terhadap Produk Permen Jelly Rumpu Laut Dengan Penambahan Konsentrasi Tepung Beras Ketan.Jurnal Agribisnis Perikanan, Vol. 11 (1).Hal.38-42.

Rakhmah, Y. 2012. Studi Pembuatan Bolu Gulung Dari Tepung Ubi Jalar (Ipomoea batatas L.). Skripsi.Jurusan Teknologi Pertanian Fakultas Pertanian Universitas Hasanuddin Makassar.

Rigap. 2013. Tili Aya. (Online). http://www.gorontalofamily.org/ 
makanan_khas/tili-aya.html.

Diakses pada tanggal 11 Maret 2018.

Saputra, KA., Pontoh, J.S., dan Momuat,

L.I. 2015. Analisis Kandungan Asam

Organik Pada Beberapa Sampel

Gula Aren. Jurnal MIPA Unsrat,

Vol. 4 (1).Hal.69-74. 